NBER WORKING PAPER SERIES

THE NEW SYSTEMS COMPETITION

Hans-Werner Sinn

Working Paper 8747

http://www.nber.org/papers/w8747

\author{
NATIONAL BUREAU OF ECONOMIC RESEARCH \\ 1050 Massachusetts Avenue \\ Cambridge, MA 02138 \\ January 2002
}

The paper was prepared for a conference at the occasion of the 50th anniversary of the Department of Economics of Norges Handelshoyskole, organised in co-operation with the Nobel Prize Centennial, December 2001. It synthesises material formerly presented in the author's Yrjö Jahnsson lectures, and at the annual meetings of the Verein für Socialpolitik, Magdeburg 2001, as well as the papers cited in the list of references. The views expressed herein are those of the author and not necessarily those of the National Bureau of Economic Research.

(C) 2002 by Hans-Werner Sinn. All rights reserved. Short sections of text, not to exceed two paragraphs, may be quoted without explicit permission provided that full credit, including $\mathbb{C}$ notice, is given to the source. 
The New Systems Competition

Hans-Werner Sinn

NBER Working Paper No. 8747

January 2002

JEL No. G1, H7

\begin{abstract}
While the old systems competition took place with closed borders, globalisation has brought about a new type of systems competition that is driven by the mobility of factors of production. The new systems competition will likely imply the erosion of the European welfare state, induce a race to the bottom in the sense that capital will not even pay for the infrastructure it uses and erode national regulatory systems. In general, it will suffer from the same type of market failure which induced the respective government activity in the first place. The new systems competition will force inefficient governments to seek national efficiency, but national efficiency does not imply that systems competition will itself be efficient.
\end{abstract}

\author{
Hans-Werner Sinn \\ CESifo and NBER \\ Poschingerstr. 5 \\ 81679 Munich \\ Germany \\ Fax: 00498992241901 \\ sinn@cesifo.de
}




\section{The new systems competition}

The unbridled economic strength of capitalist economies brought communism to its knees. Centrally planned economies took their leave from the stage of history in disgrace. Who would deny that this systems competition produced beneficial results?

This was of course a form of systems competition that has lost most of its importance today and that has given way to a new systems competition. The goal of the old systems competition between communism and capitalism was economic, cultural and military dominance, and it took place amidst closed borders in the form of mutual observation, imitation and innovation. The new systems competition, however, is a competition for locational advantage that is primarily driven by the international migration of people and production factors. In the words of Albert Hirschman (1970), exit, or voting with one's feet, characterises the new systems competition. Voice and loyalty were forces that used to play the more important roles in the competitive processes of the past.

All national economies today are confronted with the forces of globalisation. Goods and capital have been able to cross borders unrestricted for some time, and international direct investment is gaining importance. A growing number of firms are shifting their locations to low-wage and low-tax countries in order to prevail in increasingly intense international competition. At the same time, poverty refugees from all over the world are pressing into the richer industrial countries to participate in the blessings of the welfare state.

Globalisation is not a completely new phenomenon. ${ }^{1}$ Under the old colonial system, international trade and capital flows as a percentage of the national product reached significant levels. At the end of the nineteenth century one can even speak of a world labour market. This is at least the impression left by the enormous migration flows at the time. Nevertheless, with

\footnotetext{
${ }^{1}$ See Borchardt (2001).
} 
multinational corporations, the problem has now taken on new dimensions that were hardly conceivable not too long ago.

The mobility of people, goods and production factors places great competitive pressures on the countries of this world. They create a systems competition that is entirely different from the already concluded competition between communist and market-economy systems or also from the competition that the European nation states faced during the past two centuries. It is no longer a matter of implementing wise, internal policies to guide a largely autarkic economy to a position of economic strength, social peace or military dominance. The strategies of Bismarck, Stalin or Roosevelt are no longer called for. Governments today must be aware of the effects that national institutions have on the cross-border transfer of economic activities. Taxes, social transfers, public goods, regulatory systems, laws and many other factors are just as influential in motivating the movement of people and production factors as wages and other economic fundamentals that are not directly influenced by government. No state can afford to frighten off mobile capital as a result of grossly inefficient institutions, just as no state can afford to be a magnet for the poor of this world. Similar to a private company, a state competes for good customers and tries to ward off the freeloaders.

\section{The euro, capital markets and systems competition}

Understanding the new systems competition is especially important for Europe, since what has been said about the world applies in particular measure for Europe. The mobility of economic factors, the driving force of systems competition, will have a much greater impact on innerEuropean relations than brought about by the previous imitation and innovation competition of systems.

The introduction of the euro is a particularly important step in this connection because the euro is a symbol of a new liberalism and enhanced economic integration in Europe. 
People, goods, services and capital can pass borders without restrictions. The four basic freedoms, guaranteed in the Treaty of Rome already in 1957, have finally been implemented. The euro has not only helped to open doors in Europe politically. It is also directly increasing the inner-European mobility of production factors and goods. In the past, the uncertainty of exchange-rate movements has burdened cross-border trade with not inconsiderable risks and hedging costs. For Germany, The Netherlands and Austria, which were protected by the D-Mark, this brought the advantage of unmatched, low interest rates. All this no longer applies. Interest rate convergence, as shown in Figure 1, is nearly complete. The euro has created a nearly perfect inner-European capital and goods market and thus the prerequisite for a free unfolding of the forces of systems competition. 
Figure 1: Convergence of long-term interest rates

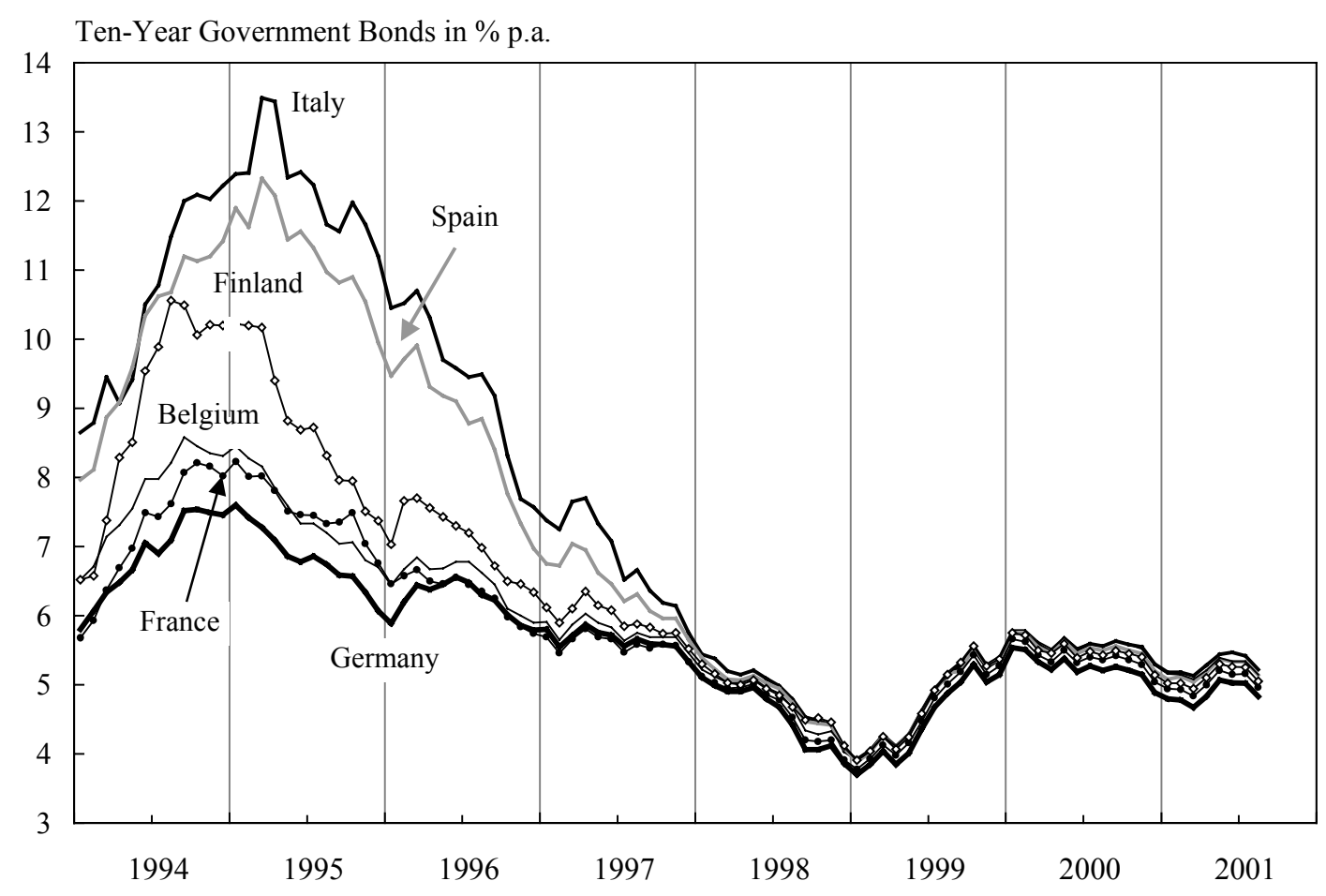

Source; Deutsche Bundesbank, Database

The German tax reform of 2000 can be seen as a reaction to this development since it was explicitly justified - as was the so-called Locational Safeguarding Law of 1994 - by the locational competition that Germany is engaged in. Germany has come in last among EU countries in recent years in terms of economic growth. The lowering of the corporation tax rate to only $25 \%$ is meant to bring a trend reversal and to prevent capital from leaving the country.

Sweden and Austria have also had extensive debates on their attractiveness as investment locations which have led to courageous tax reduction measures. Sweden and Austria have even eliminated the synthetic income tax by taxing interest income at a lumpsum rate of only $30 \%$ and $25 \%$ respectively. 
Capital reacts particularly sensitively to the taxation of interest income. After the German government announced the introduction of a $10 \%$ source tax on interest income in Autumn 1987, considerable amounts of capital left the country during the following six quarters. Long-term capital imports of DM 3 billion in the year before the announcement turned into long-term capital exports of DM 95 billion in the year after the announcement. ${ }^{2}$ The evasive reactions were so great that Germany was forced to rescind the law only four months after its introduction. The second attempt made in 1992 to tax interest income at source was only apparently successful since evasive reactions failed to materialise only because the government this time did not tax interest income earned in Germany by foreigners.

The erosive effects were not limited to the tax on interest income. Corporation income tax is also having a difficult time in systems competition. Since the dramatic income tax rate reduction from $46 \%$ to $34 \%$ that the United States introduced in 1986, many countries responded with similar tax reforms and also lowered their rates. As a result, the average effective tax burden that the present fifteen EU countries impose on US companies that operate in the EU fell by more than 12 percentage points between 1986 and 1992 (see Figure 2). Germany was merely a follower in implementing these reforms.

Ireland has pursued a particularly aggressive locational-safeguarding policy by sufficing itself with a corporation income tax rate of only $10 \%$ for an increasing number of sectors. In 1987 Ireland extended this regulation, which was originally limited to manufacturing and special service industries, also to financial services within the International Financial Service Centres in Dublin and Shannon Airport. This led to considerable capital flows to Ireland. Other governments reacted by changing legislation on external tax relations of domestic firms which allowed the revenue authorities to tax income from borrowing transactions.

\footnotetext{
2 See Nöhrbaß and Raab (1990, pp. 179-93).
} 
The Netherlands and Belgium have also followed the Irish example by granting special conditions to the financial and service industries that locate in special areas. In nominal terms they tax income at the normal corporate income tax rate, but they permit a very generous way of calculating lump sum profits which effectively reduces the corporate income tax rate to $7 \%$ (Netherlands).

Figure 2: Average tax burden for subsidiaries of US companies in European:

Reaction to US tax reforms of 1986

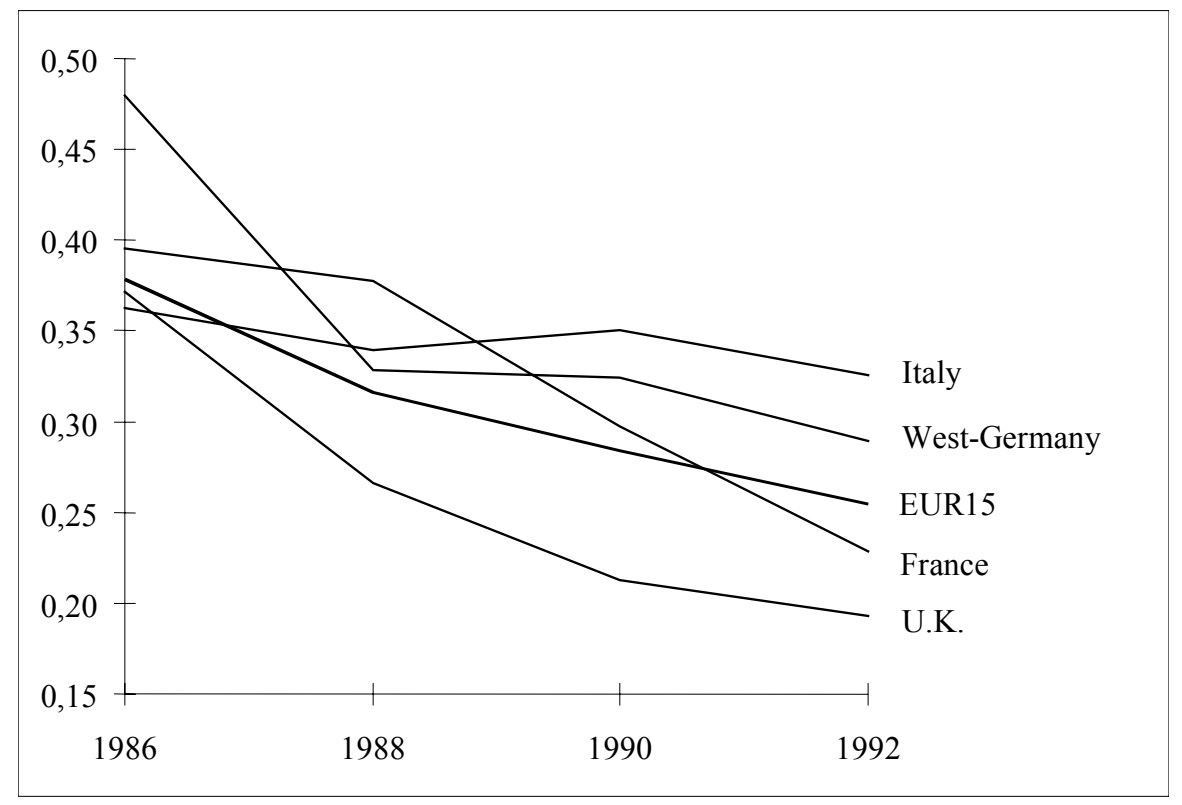

Note: The average tax burden was calculated from information from US companies on income and taxes paid for companies they control in Europe, i.e. firms of which they earn least $50 \%$ of the shares. The average tax burden is defined as the ratio of paid taxes to profits, the latter being determined by US accounting procedures. Changes in the valuation principles for determining profits are also reflected in this way in the average tax rates. The EU-15 average is calculated using GDP shares as weights.

Source: Altshuler/Grubert/Newlon (1998), Tab 1A.

There is no doubt that capital is the most mobile of all production factors. It is more mobile than labour and of course more mobile than land. For this reason it is not surprising that taxes have shifted to other factors. The factor land is not lucrative enough because of insufficient income mass. Accordingly, more and more taxes have been placed on the factor labour. 
Figure 3: The growing share of taxes on the factor labour in the OECD

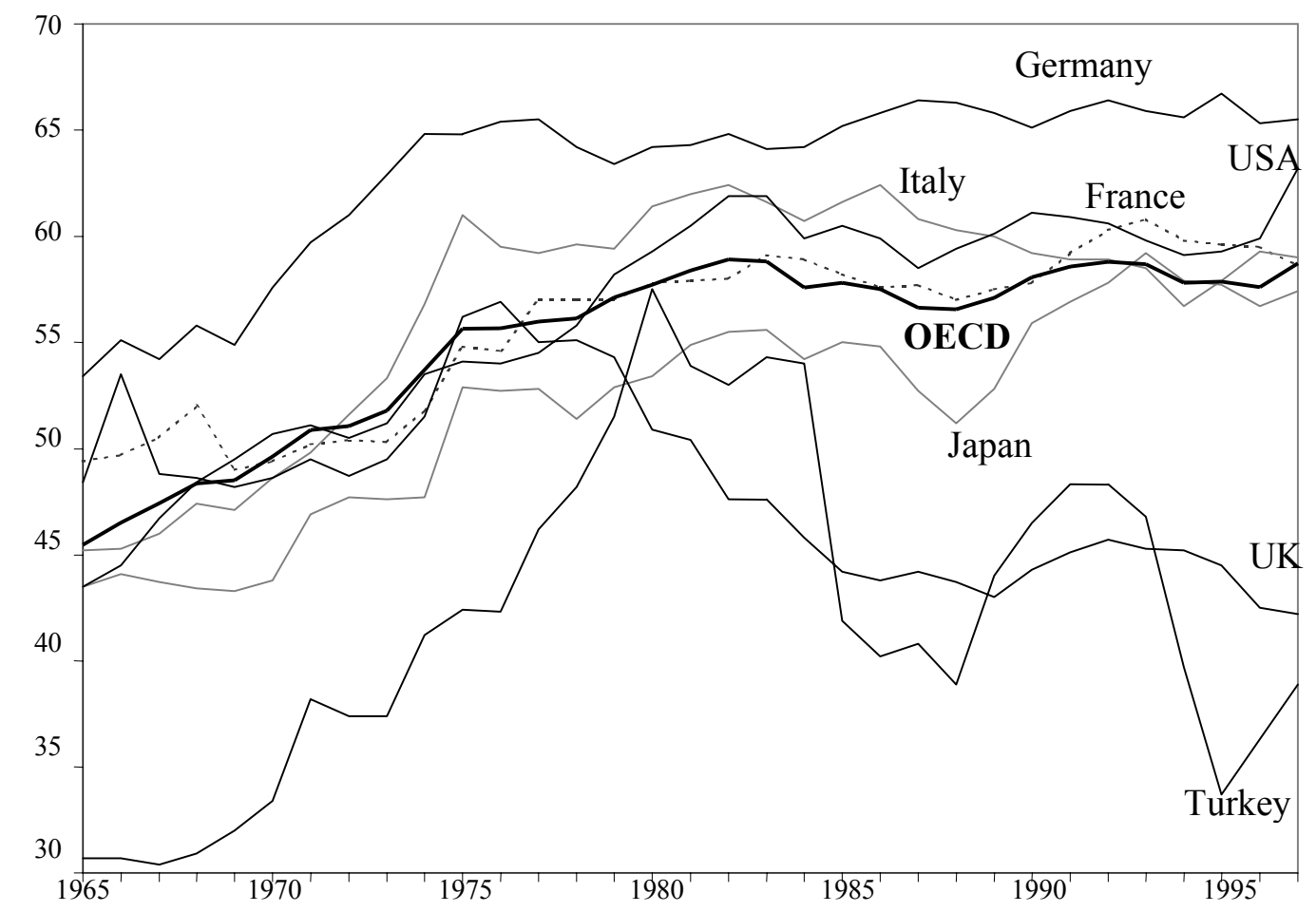

Note: Taxes on labour income as a percentage of total tax revenue, weighted by share of GDP. Taxes on labour income consist of taxes on labour income, social insurance contributions for wage earners and salaried employees based on payroll, and municipal payroll tax. Data is lacking for Mexico, Iceland, South Korea, Poland, Czech Republic and Hungary.

Source: OECD Revenue Statistics 1999, OECD National Accounts 1999, own calculations.

Figure 3 shows a clear time trend of the percentage of wage tax on total tax revenue in the OECD countries, which despite the exceptions of Turkey and the UK, is evident for most of the OECD countries. Over the past fifty years the share of wage taxes has risen from $45 \%$ to nearly $60 \%$. The factor labour is the victim of globalisation. 


\section{Migration in Europe}

Despite this trend we must not ignore the actual mobility of the labour force in Europe. Today the percentage of German residents born abroad is $8.9 \%$ of the total population. This is not much less than the $9.8 \%$ of the United States, a country of traditionally large immigration. ${ }^{3}$

Migration will increase with the eastward enlargement of the EU. No fewer than 106 million Eastern Europeans are seeking entry into the EU, and the first wave of accession will include eight countries and about 75 million people. The wage of these people is currently between one fifth and one tenth of that in west Germany, compared to about half in Spain and Portugal when they joined the EU. According to estimates by the Ifo Institute between three and four million people will migrate to Western Europe over a period of 15 years. ${ }^{4}$ Added to this is the immigration from other parts of the world.

The immigration from very poor countries to Western Europe could touch off considerable competitive pressure in the labour market. A person who decides to leave his home country to seek his fortune in the West will be guided above all by economic criteria in his choice of countries and will react to even the slightest differences. Even though considerable income differences are necessary to set off migration, the differential migration between the European countries is nevertheless extremely high. The theoretical ideal of perfect mobility is very close to being realised in this area.

Under these circumstances, the countries of Western Europe will be forced to engage in a warding-off competition so as not to attract too many people that the state would have to support. Immigrants in Germany are net recipients of government benefits during their first ten years of residence, according to a study by the Ifo Institute. Per capita and year they receive about 2,300 euros more in terms of public goods and transfers than they pay in taxes and fees. It is foreseeable that this condition will not continue. The Western European

3 OECD Society at a Glance - OECD Social Indicators 2001, Annex 1.

4 See Sinn, Flaig, Munz and Werding (2001). 
countries will scrutinise their social welfare systems and try to avoid becoming welfare magnets. A successive dismantling of the European social welfare state is the likely outcome. ${ }^{5}$

This process will, of course, be much slower than the competition for capital. It took fourteen years for Germany to adopt the American tax-cut cum base-broadening. The warding-off competition among the welfare states will be much slower. It will certainly stretch out over decades and can only be gauged in an historical perspective.

An impression of the importance of labour-force migration on the behaviour of countries can be seen in the US example. In America, labour force mobility has always been very high and at the same time the system of government is decentrally organised. Under these circumstances it was impossible to establish a European-type welfare state, and attempts that pointed in this direction failed miserably. When New York City expanded its welfare benefits under Mayor John Lindsay at the end of the 1960s as a means of combating poverty, it attracted the poor from all over America. The result was rapidly mounting debt that led to near bankruptcy in 1975 , forcing a turnaround in anti-poverty policies. ${ }^{6}$

\section{The Invisible Hand and the Selection Principle}

The major trends of systems competition are obvious and can be observed empirically. Economists also know full well what individual countries must do in the competition to attract investment. The recommendations of the various councils of economic advisors and the economic research institutes are quite unanimous in matters of tax policies and regulations. This is no wonder: economists are the "managers" of their countries. They help their respective countries to optimise their collective policy decisions. They help them survive in systems competition.

5 Network effects have little influence on this. To be sure, wherever a network already exists, the economic incentives for migration decisions are no longer so important. Then competition has already occurred. However, the expectation of future networks that may result from current migration will induce states all the more to cut back their welfare benefits. Ex ante, the competition is then all the stronger. See Thum (2000).

6 During the Lindsay's first term of office, social welfare expenses rose from $12.5 \%$ to $23 \%$ of the budget (Glaeser/Kahn 1999, p. 124; Shefter 1985, p. 86). 
What is less clear is the result that systems competition produces on the whole and especially how this result should be assessed. Can we trust this competition as an organisational process? Is there an Invisible Hand, as there is for private competition, that regulates everything for the better from the viewpoint of the community of nations? Do the Main Theorems of Welfare Economics also hold for systems competition, or is pessimism called for? Are central government solutions needed to correct the market failures in systems competition? Should policies in a variety of areas be harmonised to reduce competition? How much Brussels does Europe need? These are the fascinating questions that the theory of systems competition deals with.

It is certainly possible to construct models of systems competition whose assumptions in analogy to market competition are adjusted to producing a functional competition among states. $^{7}$ But it is not clear whether such models can capture the essence of systems competition.

The reason for doubt lies in what I once termed the Selection Principle (Sinn, 1997a, 1997b). This principle maintains that states take over those economic activities that the private market is unable to carry out. Since the state acts as a stopgap, replacing lacking markets and correcting the failings of existing markets, we cannot hope that the reintroduction of the market through the backdoor of systems competition will lead to sensible allocation results. It is more likely that the failings that led the state to act will reappear on the higher level of competition between states.

According to the Selection Principle, drawing analogies between competition in the private sphere and competition between states is completely inadmissible because the states administer the exceptions in the competitive allocation processes. Precisely because competition functions well in the private sphere it must be feared that it will fail in the public sphere.

7 See, for example, S. Sinn (1992), Richter (1994, pp. 223-340), Wellisch (1995) or Oates/Schwab (1988, pp. 333-54) and Oates (2001). 


\section{Three examples of the Selection Principle}

To show how the Selection Principle works in reality, three examples will be briefly presented, without looking at the underlying, formal models. ${ }^{8}$

\section{The erosion of the social welfare state}

Among the reasons for government redistribution, the insurance motive is probably the most important. Behind a veil of ignorance, wise constitutional fathers - or also median voters have agreed on the social welfare state to cover the life and career risks of their children. Those who suffer misfortunes in life are net recipients of state resources, the more fortunate are net payers. From an ex-ante perspective the expected utility of risk-averse citizens increases.

In establishing the redistribution measures, attention must be paid of course to the behaviour changes that they induce. Ex ante, as in all insurance contracts, the efforts to reduce the insured danger decrease, but, and this is a good thing, the willingness to take more risks in the choice of occupation and other decisions in life is greater than would otherwise be the case. Moreover, ex post, the incentive is lacing of acquiring more income through one's own efforts, which is, of course, a disadvantag.

Assume the case that a national redistribution system is optimally designed by having found the best possible mixture of these various advantages and disadvantages. Would this redistribution system survive in systems competition or was it even brought into being by this competition?

The answer is surely negative since the free migration of net payers and net recipients of state benefits would induce precisely the effect that was described in the previous two sections. Every state would have an incentive to treat the net recipients a bit worse and the net

\footnotetext{
8 For the underlying models, see Sinn (2002), Chapters 3, 2 and 7, in this order.
} 
payers a bit better that their neighbours do in order to ward off the latter and attract the former and in so doing create a budget surplus.

From the position of the individual country, given the behaviour of other countries, the utility effect for those who are induced to migrate because of this marginal decision is a negligible, second-order effect. However, the budget effect, as a first-order effect, is strictly positive. On balance with the scaling back of the social welfare state, national welfare in the sense of expected utility of the citizens increases since the budget surplus can be used to the advantage of all. From the position of all countries, however, nothing can be gained by such actions since no migration takes place when all act in this way. What happens is only that the redistribution is reduced and the expected utility of the citizens declines.

The result can also be understood by using the theory of externalities. The social welfare state creates positive external effects for other social welfare states by means of the international migration that it induces. It drives away the rich, increases the supply of factors offered by them in other countries and in this way lowers their factor payments abroad. And it attracts the poor, whereby their factor payments rise elsewhere. In this way the income distribution in other countries becomes more even and the degree of goal performance of social policy in these countries rises. Since the positive external effects are not taken into consideration in national social policies, systems competition brings about an underprovision of social policy.

The underlying cause for this flaw in systems competition can be seen in the Selection Principle since the protection against inequality in lifetime income that the social welfare state offers cannot be provided by private enterprise. Private insurance contracts presuppose that the signers are of age and can only be concluded with adults. For an adult, however, the dice of fate have already been cast, the veil of ignorance has been lifted. ${ }^{9}$ Redistribution contracts do not come into being on a private enterprise basis since the mobile net payers would not

9 In theory it is conceivable that parents conclude such contracts for their children, but no civilised country gives parents the right to obligate their successful children to pay for the unsuccessful children of other people. Only contracts that involve a resource transfer from parents to children are allowed. 
participate. Adverse selection prevents the private insurance market from coming into existence.

The migration processes that create a failure in the competition among social welfare states can also be interpreted as adverse selection. The migration of the successful and the unsuccessful is a choice that takes place ex post, that is after the veil of ignorance has already been lifted. Since the successful net payers do not participate, the social welfare state cannot survive.

A possible policy implication of this lies in the harmonisation of redistribution rules, but this is not easily achievable between countries with differing average incomes. What is better is a delayed integration of migrants in the national social system, as has been recommended by the Advisory Council to the German Ministry of Finance or recently by the Ifo Institute. ${ }^{10}$

\section{Infrastructure goods and the race to the bottom}

It is often maintained that there is no need to fear the erosive forces of systems competition. There is no race to the bottom since the net payers do not orient themselves on the taxes that they pay but on the public goods that are placed at their disposal. There is especially no need to fear a race to the bottom in the competition to attract mobile capital since companies are prepared to pay an appropriate price for good infrastructure. This argument is true on the surface, but it is only half the truth.

First of all, it would be bad enough for the social welfare state if the taxes that are paid on the factor capital would only suffice to pay for the infrastructure made available to this factor. They would lose their fiscal character and become pure benefit taxes, because this would mean foregoing redistribution and insurance protection.

10 Sinn, Flaig, Munz, Werding (2001) and Wissenschaftlicher Beirat beim Bundesministerium der Finanzen (2000) 
Secondly, it is not even certain that the taxes on mobile capital generate enough revenue to pay for the infrastructure. In systems competition, countries behave like competing firms that demand marginal cost prices, or to be more precise, tax rates that reflect the marginal congestion costs for a given infrastructure. It is not to be expected that these tax rates will provide enough income to cover the costs of providing the infrastructure.

The reason for this lies in the Selection Principle. When states are designed in accordance with this principle, they offer those goods which because of sufficiently strongly increasing returns to scale in production and use cannot be offered by the private sector, since private competition would be ruinous and would not achieve equilibrium. For such goods, tax rates or prices as high as the marginal congestion costs are not enough to finance the infrastructure. A chronic deficit arises that must be covered by other means. The private market failure that led to state intervention has renewed, problematic implications at the higher level of competition between countries.

When the immobile production factors are sufficiently important this does not automatically mean that there is no equilibrium in systems competition. Also competition is not inefficient. It is in the interest of the owners of immobile factors, which are complementary to mobile factors, to co-finance the infrastructure used by the mobile factors. Moreover, the individual state has the incentive of providing the right quantity and quality of infrastructure. Nevertheless, the result for the social welfare state is still worse than if only benefit taxes can be levied. The owners of immobile factors, which include very many infirm, weak, or those who offer simple labour, receive no money from the rich capital owners but subsidise these capital owners in systems competition. This is not a race to the bottom but in a certain sense a race below the bottom.

The policy implications of this observation are similar to those that can be derived from the erosion of the social welfare state. In addition, locational competition can be limited if cross-border profit flows are taxed according to the residence principle instead of the source 
country principle. The US Internal Revenue Service with its world-wide income concept and its regulations for taxing passive foreign income has gone quite far in this direction.

A harmonisation of corporate income tax in the European context does not follow from this because such a step would likely lead countries to conduct locational competition with infrastructure goods which would lead to an oversupply of such goods. When there is harmonisation it must also be assured that the infrastructure used by the mobile factors is completely paid by them. This could be achieved by an extension of the EU subsidy bans to include indirect assistance from infrastructure gifts. Given that the EU is just now considering new proposals for a harmonisation of company taxes, this is a timely issue.

\section{Lemon banks and bank regulation}

The third and last example to be considered deals with bank regulation. ${ }^{11}$ The Asia crises, the US Savings and Loan crisis and various bank failures have shown that regulation of the banking sector is an important task for the state and that there are possibly problems with a free regulatory competition. Not least as a result of these crises, the Bank for International Settlements is currently improving its rules for bank regulation (Basel II) to promote, on this basis, a further harmonisation of national rules.

The purchaser of a bank bond does not receive a guaranteed redemption claim. Instead, the likelihood of the agreed redemption depends on whether the bank has not gone bankrupt before the repayment date, and the amount of repayment in case of bankruptcy depends on how much capital reserves the bank has, to service their creditors even in a worst-case scenario. Banks are not able to completely avoid bankruptcy because the companies to whom the banks pass on the funds they received from the purchasers of bonds are also not immune to bankruptcy. The expected redemption value is the key quality feature of a bank bond. If the true expected value cannot be determined by the bank's creditors because the creditors cannot

${ }^{11}$ For the formal model underlying the analysis of this section see Sinn (2001). 
effectively monitor the bank's actions, the bank bond is a lemon good whose quality is exposed to erosive forces similar to those that effect physical lemon goods.

In the case of asymmetric information between a bank and its creditors there is the danger of excessively negligent bank behaviour. The bank may have an incentive to conduct its business with excessively low capital reserves and to finance particularly risky enterprises. In the choice between an extended loan that has a high probability of a modest return and one with a low probability of a high return, it can be worthwhile to choose the second alternative even if a smaller expected rate of return is associated with it. The reason lies in what I once called the BLOOS rule which states that you cannot get blood out of a stone. ${ }^{12}$ Since a bank cannot lose more than its capital reserves, the acceptance of a smaller chance of success and thus a larger risk of bankruptcy has the advantage that the expected redemption value that the bank must give its own creditors is reduced. The expected profit of the bank can be enlarged in a similar way as the profit of a lemon supplier can be enlarged by a quality deterioration of the sold product.

If all banks in a market behave this way, then the buyers of bank bonds can conclude from observing the occasional bank failure that they are buying lemon bonds and they will demand appropriate risk premia on top of the agreed interest rate. To this extent they are not cheated in the final analysis and to this extent banks as a whole do not succeed in putting themselves in a better position by increasing the risk of bank failure. On the contrary, because they choose excessively risky and unprofitable financing projects the lessening of expected loan repayments from these projects will be expressed in a reduction of expected bank profits. The welfare loss that results from the lemon bonds will be borne entirely by the banks themselves.

It is in the interest of the banks to prevent the development of such a lemon equilibrium by means of collectively agreed or government ordered rules on capital reserves.

\footnotetext{
12 See Sinn $(1980,1982)$.
} 
Strict bank supervision, as is carried out in Western industrial countries, solves the allocation problem.

Unfortunately, the Selection Principle again indicates dangers if bank supervision itself is exposed to international competition. Assuming that bank customers are neither able to reliably assess the risk situation of the individual bank nor the importance of national rules on

bank reserves, the national regulatory agency has an incentive to be generous in controlling the banks under its supervision if foreigners are among the holders of bank bonds. The loosening of the regulatory restrictions behind the backs of the creditors leads to a redistribution from these creditors to the national banks, and the larger the percentage of foreigners among the creditors, the larger the national welfare gain that arises. National market failure translates into a competition of laxity of the regulatory agencies and thus to a failure of systems competition.

Noted economists have attributed the Asian crisis of 1997 and 1998 to an excessively lax regulation of Asian banks, and there are many indications that systems competition resulted in overly lax regulation. In this regard, the efforts of the Bank for International Settlements to achieve a better de facto harmonisation of bank regulation with the Basel II accord is a step in the right direction.

\section{Concluding remarks}

Similar examples could be added from environmental policy, health care or other areas. They would confirm that because of the Selection Principle the more likely outcome is a failure rather than a smooth functioning of systems competition.

The implications for the necessity of international agreements and harmonisation measures including the development of a new level of government in Europe are obvious and must be taken seriously. Of course, we know all too well that market failure is not a sufficient reason for government intervention or, for that matter, that a failure of the competition among the European nation states is not a sufficient reason for Brussels to step in. The danger that the 
central authority will do an even poorer job than the market participants is too great. We should be careful, however, not to throw out the baby with the bath water. The proof of failure in systems competition is the necessary prerequisite for considering international regulations in the first place. In this respect the Selection Principle is important for a new design of Europe and the world. It destroys the wishful thinking that some economists, enamoured by their firm belief in competitive processes, engage in.

A counter-thesis to the pessimism that follows from the Selection Principle is that systems competition is desirable because it forces inefficient countries to become more efficient. This thesis follows the same logic as the view that private competition eliminates inefficient companies or forces them to act efficiently. Indeed, much can be said for this thesis under ideal market conditions. Inefficiently managed firms have high average costs and are forced to mimic efficiently managed firms with lower costs, if they do not want to perish. The Main Theorems of Welfare Economics probably also apply, if the managers selected by the market process are too stupid to actively implement the conditions for a profit maximum, but clever enough to mimic successful competitors who by chance picked the right policies.

The problem, however, is the assumption of ideal market conditions. If such conditions are not present, is not easy to talk about the efficiency promoting effects of competition. Consider the example of environmental pollution to clarify the point. Without competition, a management with a romantic, nature-loving orientation could survive but under competition it has no chance. Businesses that maximise their profits and minimise their operating costs will prevail, and these are the environmental polluters.

The Selection Principle states that ideal market conditions tend to exist in private competition but not in competition between states, and this raises doubts as to the efficiency of systems competition even if national governments are too ignorant to actively pursue a policy of national welfare maximisation. For a similar reason as in the case of private firms, competition will force even the badly functioning governments to mimic their successful neighbours which managed to find better policy mixes with regard to the mobile factors of 
production, but, as explained, such policy mixes need not be better from an international welfare perspective. In the above-mentioned examples a maximum of nation state efficiency was assumed. The behaviour of individual countries served the goal of maximising national welfare. Despite, or better, because of the perfect achievement of this goal, systems competition turned out to be defective. As correct as the thesis that systems competition forces the nation state to seek national efficiency is, it does not follow from this that systems competition itself is efficient.

The Selection Principle is in accord with the positive view of the state that stems from traditional public sector economics as represented by Schäffle (1880), Sax (1887), Wagner (1876), Wicksell (1901), Lindahl (1939), Musgrave (1959), Timm (1961) and others. For this tradition the modern state is a necessary accompanying feature of industrialisation and urbanisation touched off by the Industrial Revolution. It arose above all to correct the deplorable conditions that were characteristic of the late nineteenth century. Cities choked in filth, the pitiable living conditions of the proletariat, poverty among the elderly, catastrophic hygienic conditions, and many other evils gave rise to a general need for government intervention in the market process. The modern European state is not a ruling instrument of feudal powers. Despite all its weakness and problems, it must be seen as an instrument for the fulfilment of collective tasks that cannot be accomplished by the private market. It is not the result of an error of history but its logical consequence. In systems competition, however, its chances are no longer all too great.

The historical selection of government tasks came about in part by competitive processes. But this was not a systems competition forced by the international mobility of production factors, but the innovation and imitation competition described at the outset, which among other things was guided by the objective of economic, cultural and military dominance and which took place within largely sealed borders. Such competition follows completely different laws than competition induced by the mobility of production factors. Indeed, in the light of the Selection Principle it is conceivable, or even likely, that the new systems 
competition will destroy the results of the old if we do not succeed in drastically limiting its scope. 


\section{References}

Altshuler, R., H. Grubert and S. T. Newlon (1998), "Has U.S. Investment Abroad Become More Sensitive to Tax Rates?," NBER Working Paper 6383.

Borchardt, K. (2001), "Die Globalisierung ist nicht unumkehrbar," Handelsblatt No. 112 of 13. 6. $2001,7$.

Glaeser, E. L., and M. E. Kahn (1999), "From Lindsay to Rudy Giuliani: The Decline of the Local Safety Net?," Economic Policy Review 5, 117-32.

Hirschman, A. O. (1970), Exit, Voice and Loyalty: Responses to Decline in Firms, Organizations, and States. Harvard University Press: Cambridge.

Lindahl, E. (1939), Studies in the Theory of Money and Capital, George Allen \& Unwin Ltd.: London.

Musgrave, R. A. (1959), The Theory of Public Finance. McGraw-Hill: New York.

Nöhrbaß, K. H., and M. Raab (1990), "Quellensteuer und Kapitalmarkt," Finanzarchiv 48, 179-93.

Oates, W. E. (2001), "Fiscal an Regulatory Competition: Theory and Evidence," paper presented at the annual conference of the Verein für Socialpolitik in Magdeburg, September 2001.

Oates, W. E., and R. M. Schwab (1988), "Economic Competition among Jurisdictions: Efficiency Enhancing or Distortion Inducing?," Journal of Public Economics 35, 333 54.

Richter, W. F. (1994), "The Efficient Allocation of Local Public Factors in Tiebout's Tradition," Regional Science and Urban Economics 24, 323-40.

Sax, E. (1887); Grundlegung der theoretischen Staatswirtschaft. Hölder: Vienna.

Schäffle, A. E. (1880), Die Grundsätze der Steuerpolitik und die schwebenden Finanzfragen Deutschlands und Österreichs. Laupp: Tübingen.

Shefter, M. (1985), Political Crisis, Fiscal Crisis - The Collapse and Revival of New York City. Basic Books: New York. 
Sinn, H.-W. (1980), Ökonomische Entscheidungen bei Ungewißheit. Mohr: Tübingen. Here cited according to the English translation: Economic Decisions under Uncertainty. North-Holland Publishing Company: Amsterdam, New York and Oxford 1983.

--- (1982), "Kinked Utility and the Demand for Human Wealth and Liability Insurance," European Economic Review 17, 149-62.

--- (1997a), "The Selection Principle and Market Failure in Systems Competition," Journal of Public Economics 66, 247-74.

--- (1997b), "Das Selektionsprinzip und der Systemwettbewerb," in: A. Oberhauser, ed., Fiskalföderalismus in Europa. Duncker \& Humblot: Berlin, 9-60.

--- (2001), "Risk Taking, Limited Liability and the Competition of Bank Regulators," CESifo Working Paper No. 603, November 2001.

--- (2002), The New Systems Competition. Yrjö Jahnsson Lectures 1999, Basil Blackwell: Oxford and Malden, Mass., forthcoming.

Sinn, H.-W., G. Flaig, S. Munz und M. Werding (2001), EU-Erweiterung und Arbeitskräftemigration: Wege zu einer schrittweisen Annäherung der Arbeitsmärkte. Ifo Beiträge zur Wirtschaftsforschung 2, ifo Institut für Wirtschaftsforschung: Munich.

Sinn, S. (1992), "The Taming of the Leviathan: Competition among Governments," Constitutional Political Economy 3, 177-96.

Thum, M. (2000), "EU Enlargement, Fiscal Competition and Network Migration," mimeo, University of Munich.

Timm, H. (1961), "Das Gesetz der wachsenden Staatsausgaben," Finanzarchiv 21, 201-47.

Wagner, A. (1876), Allgemeine oder theoretische Volkswirtschaftslehre: Erster Theil. Grundlegung. Winter'sche Buchhandlung: Leipzig and Heidelberg.

Wellisch, D. (1995), Dezentrale Finanzpolitik bei hoher Mobilität. J. C. B. Mohr (Paul Siebeck): Tübingen.

Wicksell, K. (1901), Lectures on Political Economy, Vol. 1. 1967 reprint of 1934 edition, Augustus M. Kelley: New York.

Wissenschaftlicher Beirat beim Bundesministerium der Finanzen (2000), Freizügigkeit und Soziale Sicherung in Europa. BMF-Schriftenreihe 69, Bonn. 